\title{
Aspectos distintos da paixão da nostalgia na construção dos sujeitos dos enunciados nas canções de Nando Reis
}

Lilian Maria MARQUES E SILVA

(Universidade de Franca)

RESUMO: As diferentes manifestações da paixão da nostalgia, ora verdadeira, ora mentirosa, muitas vezes pontual, tendo por base a teoria semiótica greimasiana, é o nosso objeto de estudo nas canções "Pra ela voltar", "Mesmo sozinho" e "N", compostas e interpretadas por Nando Reis.

PALAVRAS-CHAVE: paixão; nostalgia; sujeito; canção

ABSTRACT: The different manifestations of nostalgia passion, now true, then false, many times, punctual, based on the Greimassian semiotics theory, is our object of study in the songs "Pra ela voltar", "Mesmo sozinho" and " $N$ ", written and interpreted by Nando Reis.

KEYWORDS: passion; nostalgia; subject; song 


\section{INTRODUÇão}

Os estudos semióticos, a partir dos anos 80 , começam a considerar no nível narrativo não apenas um sujeito movido pelas modalidades do ser e do fazer- o querer, o dever, o poder e o saber - o sujeito operador; mas passam a considerar, com certa relevância, os estados do sujeito. Iniciam-se, dessa forma, os estudos da semiótica das paixões, os efeitos de sentido de qualificações modais que modificam o sujeito de estado. Essas qualificações organizam-se, segundo Diana L. P. de Barros (2001:47) sob a forma de arranjos sintagmáticos de modalidades ou configurações passionais.

Neste artigo abordaremos a paixão da nostalgia e as formas como ela se manifesta na construção do sujeito em três canções de autoria de Nando Reis: "Pra ela voltar" (Nando Reis, 2006, faixa 10) e "N" (Nando Reis, 2006, faixa 3) do álbum Sim e não e os infernais, "Mesmo Sozinho" (Nando Reis, 2003, faixa 8), do álbum A letra A. Para melhor compreensão, as letras estão anexas ao final do texto.

Tentaremos evidenciar como uma mesma paixão manifesta-se de forma diferente conforme o sujeito que a sente. Tais manifestações passionais, embora muito freqüentes, principalmente em textos literários, nos chamaram a atenção pelo fato de encontrarmos poucos semioticistas que tratam especificamente da paixão da nostalgia no que tange à teoria semiótica francesa e que não se preocupam em descrever tais manifestações nostálgicas. Dessa forma, nossas análises objetivam colaborar para caracterizar melhor a paixão da nostalgia.

\section{ANÁLISES}

\section{- "PRA ELA VOLTAR"}

A paixão da nostalgia, segundo Bertrand (2003), marca a persistência, na memória do sujeito, de uma conjunção terminada.

Em "Pra ela voltar" o sujeito enunciador revela-se nostálgico por estar em disjunção com o objeto-valor "ela". A leitura nos leva a perceber que este sujeito nostálgico já esteve, um dia, em conjunção com o seu objeto-valor logo no primeiro verso da canção "Desde que ela foi embora”. $\mathrm{O}$ ato de ir embora pressupõe que houve a presença em um momento anterior deste objeto-valor em uma cena enunciativa passada. A paixão da nostalgia, fortemente marcada em toda a letra, é fruto desta disjunção entre o enunciador - sujeito nostálgico - e o próprio objeto-valor - ela. O título da canção "Pra ela voltar" nos faz crer que há esperança de um retorno do objeto-valor por parte do enunciador, o que caracteriza um sujeito nostálgico. Esse sujeito é fortemente marcado por uma esperança de /querer-ter/ seu objeto-valor conjunto a ele. O prórpio título da canção nos propicia observar essa vontade da conjunção entre ambos - sujeito enunciador e objeto-valor.

A oposição semântica, no nível profundo é a solidão vs companhia que revela o sentimento de tristeza no sujeito actorial.

Inicia-se o texto com uma debreagem enunciva, criando um efeito de distanciamento, em terceira pessoa - ela -, no espaço do lá e no tempo do então passado -, na qual o enunciador nos apresenta seu estado de nostalgia, revelando-se um 
sujeito triste, deprimido, com a falta deste objeto-valor: a amada. Logo em seguida, tem-se a debreagem enunciativa - efeito de proximidade - presentificando a cena, envolvendo pessoa (eu), espaço (aqui: casa) e tempo (agora). Analisando em uma perspectiva semiótica algumas letras de canções, Tatit (2001:41) alude à importância desses recursos enunciativos que têm na noção de saudade o seu elemento propulsor. A relação entre passado e presente assegura o intervalo necessário à manifestação desse sentimento.

O enunciador é modalizado pelo querer e pelo crer. Ele clama a alguém à volta/retorno de sua amada "Diga que é pra ela voltar/Que sem ela eu não passo nada bem”; e acredita ou quer-crer e fazer-crer que é extremamente fundamental a sua volta, o seu regresso, ou seja, tenta persuadir, sem sucesso, que não é possível, de ambas as partes, viver solitário, um sem o outro.

"Pra ela voltar” é um texto figurativo e temático. As figuras: o galo, a roupa, a Lua, os móveis da casa etc. recobrem os temas "sofrimento", "angústia”, “tristeza” e “solidão". Tais figuras criam um efeito de sentido de verdade reiterado por meio das isotopias visuais (o brilho da lua apagado, a nuvem de chumbo), auditivas (o cantar do galo, o assopro do apito do guarda-noturno, o barulho no silêncio) e táteis (roupa molhada, o fechar da porta, o ascender da luz).

A sanção deste percurso é disfórica para o enunciador que sofre com as lembranças desde o dia que seu objeto-valor partiu até o presente em que quer-crer na sua volta. O sujeito inicia e termina todo seu o seu percurso narrativo em disjunção com o objeto-valor, não adquire a competência de trazê-lo de volta e se revela um sujeito nostálgico, saudoso.

\section{- “MESMO SOZINHO”}

Em “Mesmo sozinho" o compositor também utiliza o recurso enunciativo da debreagem temporal, ora remete ao passado - debreagem enunciva - ora ao presente debreagem enunciativa. É muito importante, até mesmo imprescindível, enfatizar este recurso, pois é através dele que se resgata a memória do enunciador, trazendo as lembranças que resultam a paixão "nostalgia”.

A letra apresenta um conflito interno do enunciador permeado por emoções e questionamentos.

O que difere o sujeito nostálgico desta canção com a já analisada "Pra ela voltar" é que este sujeito tenta negar o "não-ser", o sentimento nostálgico característica que distingue uma nostalgia da outra já analisada, pois o enunciador não admite o sentimento da falta; o que não acontece na canção anterior - o seu sujeito explicita o seu /querer/ e o /querer-crer/ na volta do seu objeto-valor. Pode-se afirmar, então, que a modalidade do ser e do parecer em "Mesmo sozinho", denominada veredictória, é mentirosa e que há nostalgia distinta conforme o sujeito da enunciação que a sente. A modalidade da "mentira" é o parecer, mas o não-ser, pois o que parece ser de fato não o é - o enunciador tenta mostrar-se bem, normal; diz estar feliz e em paz, mesmo sozinho; o que não é verdade. Nos versos 20 e seguintes lê-se "Sabe do que eu sinto saudades?/Do seu sorriso de manhã/Do quarto tão desarrumado” - narra o desejo 
em tê-la de volta, mas em momento algum no texto esse desejo é admitido pelo enunciador. Ele tenta se esquivar da verdade: “estou vivendo normalmente” - como se estivesse tudo bem; mas já na segunda parte do texto, este mesmo verso substitui o advérbio de modo normalmente pelo advérbio, também de modo, simplesmente. Conclui-se que viver - um ato involuntário - é o que lhe restou diante da ausência do objeto-valor.

A paixão da nostalgia é enfatizada na quinta estrofe da letra da canção. O sentimento da saudade é exaltado e admitido pelo eu-enunciador que descreve o que mais lhe faz falta - o sorriso da amada logo pela manhã e o quarto desarrumado. A ausência do objeto é tão intensa que até a desordem do seu quarto (característica geralmente vista como negativa), faz falta em seu dia-a-dia.

A partir da terceira estrofe, a presentificação do tempo se torna nítida pelo uso dos verbos no gerúndio (vivendo, pensando e chorando), criando um efeito de sentido de verdade e de proximidade.

A narratividade em "Mesmo sozinho" se inicia com o sujeito sem a competência necessária para manter-se junto ao objeto, resultando numa sanção negativa, disfórica. Em determinado momento, no texto, o enunciador revela o desejo de saber que este objeto - ela - esteja feliz mesmo em conjunção com um outro sujeito um rival, um oponente. Embora a narrativa possua, de forma implícita, um triângulo amoroso, não há neste texto, a paixão do ciúme revelada por parte do enunciador. Ora mostra-se conformado, ora nostálgico, indagando e procurando na memória a presença da amada.

O universo passional, segundo Tatit (2001:35-39) o sujeito alimenta-se de duração. É necessário tempo para a configuração do mundo sensível do enunciador. Para esquecer em superfície, é necessário recordar em profundidade. O descontínuo próprio do universo inteligível pressupõe o continuo do mundo sensível. Dessa forma, a nostalgia visa o esquecimento, mas estabelece a recordação, a memória.

O uso do termo estrangeiro "baby" remete ao adjetivo "querida” reforçando o elo contínuo entre sujeito/objeto. As tensões geradoras da paixão nostálgica decorrem do sentimento da falta deste elo, que inexiste em todo o percurso da narratividade.

- “N”

Em “N” evidencia-se pelo menos três paixões: a nostalgia, o medo e o amor. O que nos interessa aqui é a paixão da nostalgia. O enunciador revela-se um sujeito questionador, nostálgico, com medo de perder seu objeto-valor que se encontra em uma disjunção momentânea. Trata-se de dois sujeitos que se distanciam (disjunção) durante os dias da semana:

[...] espero que a semana acabe para que eu possa te ver de novo [...].

A paixão do amor é mostrada pelo sujeito enunciador que permanece com "os lábios molhados”, “chorando” e até mesmo, sentindo seu "cheiro no travesseiro” e que 
aguarda a sua volta. O choro e a percepção de odores de sua amada também revelam a paixão da nostalgia - saudade do objeto-valor.

O sujeito afirma não ser possível esquecer seu objeto-valor já que tem em seu braço a tatuagem que simboliza um elo entre eles - uma letra comum tanto a seu nome como a seu objeto valor:

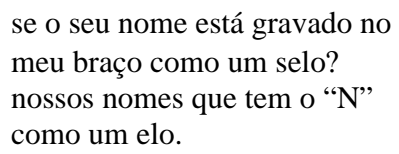

No nível fundamental, encontramos a seguinte oposição semântica: presença vs ausência. É essa oposição semântica que resulta características distintas da paixão da nostalgia - ora profunda e permanente, ora superficial e pontual.

No nível narrativo, a leitura nos permite perceber um sujeito disjunto de seu objeto-valor: S U O que gera a paixão da nostalgia.

Esta disjunção, embora seja momentânea, não-definitiva, leva o enunciador a questionamentos e a sentir medo e nostalgia justamente por existir entre os dois, a paixão do amor. A paixão do amor, segundo Aristóteles, "é certamente um vínculo de identidade mais ou menos parcial. É o próprio lugar da conjunção, da associação” (2000:XLIV).

O recurso enunciativo da debreagem remete a primeira pessoa “eu”, ao espaço "aqui” e ao tempo do "agora” (presente) - debreagem enunciativa.

As lembranças resgatadas na memória do enunciador são as responsáveis por gerar a paixão "nostalgia” e a ausência temporária do objeto-valor gera o “medo”.

O enunciador é modalizado pelo /querer/ e pelo /crer/. Ele quer-ter sua amada perto de si e acredita fielmente nisto, deseja, torcendo para que o tempo "voe".

Não é relatada a sanção do percurso canônico em "N". Subentende-se que será positivo/eufórico, pois é sabido que a disjunção é momentânea; mas na letra não é mostrada/enunciada a conjunção entre o sujeito e objeto-valor.

A modalidade do ser e do parecer é verdadeira - as ações e os valores do enunciador parecem e são, de fato, reais - os sentimentos de saudade, nostalgia, medo e amor são verdadeiramente sentidos pelo enunciador.

Trata-se e um texto figurativo e temático. Esses procedimentos do nível discursivo predominam durante toda a canção. As figuras lábios, lágrimas, sol, cheiro, cabelo, peito, semana, tempo, nome, selo, braço, elo, “N” e corpo desencadeiam as isotopias temáticas da saudade, sofrimento, solidão, angústia e do próprio amor.

Há no texto também isotopias táteis (lábios molhados, cabelo no peito, tatuagem na pele) e olfativas (cheiro no travesseiro), revelando, assim, a paixão do amor do sujeito para com seu objeto-valor. Essas isotopias presentificadas na cena enunciativa imprimem ao texto a modalidade veredictória da verdade.

\section{CONCLUSÃo}

No percurso passional, as modalidades do /querer/, /poder/, /não-poder/ e do /crer/ produzem efeitos de sentido da paixão nostalgia pelo objeto-valor não adquirido "ela" 
(o não poder-ter) ou pelo distanciamento momentâneo do objeto-valor "ela”, gerando valores da insatisfação e da infelicidade.

Diante disso, por meio da análise semiótica greimasiana, evidenciamos que em "Pra ela voltar" e "Mesmo Sozinho" a paixão da nostalgia é narrada e sentida pelos enunciadores e que os percursos passionais se diferenciam quanto às modalidades veredictórias, em que uma é verdadeira e a outra mentirosa. No nível discursivo, as duas canções desencadeiam o mesmo percurso passional caracterizando uma mesma paixão a nostalgia.

Em "N", ocorre a debreagem enunciativa (eu aqui agora) que enfatiza as paixões da nostalgia, do medo e do amor. A letra revela um sujeito nostálgico, com medo da distância entre seu objeto-valor (seu amor) mesmo, constatado através do texto, de que se trata de uma disjunção momentânea, tornando a nostalgia uma paixão pontual - daquele momento apenas.

A paixão da nostalgia no nosso corpus de análise é manifestada de maneira distinta conforme cada enunciação e, assim, são reveladas paixões nostálgicas verdadeiras, falsas e até mesmo pontuais - aquelas que não são duradouras, que são cíclicas.

\section{REFERÊNCIAS BIBLIOGRÁFICAS}

ARISTÓTELES. Retórica das paixões. São Paulo: Martins Fontes, 2000.

BARROS, Diana Luz Pessoa de. Teoria semiótica do texto. São Paulo: Ática, 1990.

BERTRAND, Denis. Caminhos da semiótica literária. Bauru: EDUSC, 2003.

GREIMAS, Algirdas Julien \& COURTÉS, Joseph. Dicionário de semiótica. São Paulo: Cultrix, 1979.

NANDO REIS. "N". In: Sim e não e os infernais [CD]. Rio de Janeiro: Universal Music, 2006. "Pra ela voltar". In: Sim e não e os infernais. [CD]. Rio de Janeiro: Universal Music, 2006.

"Mesmo sozinho". In: A letra A. [CD]. São Paulo, Rio de Janeiro e EUA: Universal Music, 2003.

TATIT. Análise semiótica através das letras. São Paulo: Ateliê Editorial, 2001.

\section{Anexos}

Anexo 1 - Pra ela voltar (letra)

Desde que ela foi embora

Nada mais funcionou

O galo canta muito antes da aurora

E a roupa ainda não secou

Mesmo a Lua que brilhava lá fora

Uma nuvem de chumbo apagou

O guarda-noturno assopra

Só pra me lembrar que acabou

Um muro separa o mundo lá fora

A água do poço secou

$\mathrm{O}$ vidro embaça se meus lábios encostam 
Num beijo que não me tocou

Diga que é pra ela voltar

Que sem ela eu não passo nada bem

Que duas pessoas não deixam

de amar

que uma pessoa só não conta

que uma pessoa só não é ninguém

Escuto o barulho no silêncio

Que chora

Não reconheço esse som

Não ouço o riso que ouvia outrora

Pois seu sorriso ela levou

Eu entro sozinho e fecho a porta

Acendo a luz e não encontro mais ninguém

os móveis antigos que morrem na sala

estão só pra me lembrar que acabou.

Anexo 2 - Mesmo Sozinho (letra)

Uh... Baby!

Por que você foi pra tão longe?

Não precisava tanto

Bastava só não telefonar.

Uh...Baby, Baby, Baby!

$\mathrm{O}$ que aconteceu?

$\mathrm{O}$ ar não foi suficiente?

Você não viu, você sumiu

Mudou de lugar

No mais estou vivendo normalmente

Não vou ficar pensando

Se tivesse sido o contrário

Estou feliz

Mesmo sozinho

Esse silêncio é paz

Nesse momento cai

Uma forte chuva

Quem vai ficar chorando?

Uh... Baby!

Sabe do que eu sinto saudades?

Do seu sorriso de manhã

Do quarto tão desarrumado

Uh... Baby!

Saiba que eu gosto muito de você

Espero que esteja feliz

E bem acompanhada

Normal, estou vivendo, simplesmente

Não vou ficar pensando

Se tivesse sido o contrário

Estou feliz

Mesmo sozinho

Esse silêncio é paz 
Nesse momento cai

Uma forte chuva

Quem vai ficar chorando?

Anexo 3 - "N" (letra)

E agora, o que eu vou fazer

Se os seus lábios ainda

Estão molhando

Os lábios meus?

$\mathrm{E}$ as lágrimas não secaram

Com o sol que fez?

E agora como eu posso te esquecer

Se o seu cheiro ainda

Está no travesseiro?

E o seu cabelo está enrolado

No meu peito?

Espero que o tempo passe

Espero que a semana acabe

Pra qu'eu possa te ver de novo

Espero que o tempo voe

Para que você retorne

Pra qu'eu possa te abraçar

E te beijar

De novo

E agora como eu passo sem te ver?

Se o seu nome está gravado no

Meu braço como um selo?

Nossos nomes que tem o $\mathrm{N}$

Como um elo

E agora, como posso te perder?

Se teu corpo ainda guarda o

Meu prazer?

E o meu corpo está moldado

Com o teu?

\section{Como citar este artigo:}

MARQUES E SILVA, Lílian Maria. Aspectos distintos da paixão da nostalgia na construção dos sujeitos dos enunciados nas canções de Nando Reis. Estudos Semióticos. [online] Disponível na Internet via WWW.URL: http://www.fflch.usp.br/dl/semiotica/es. Editor Peter Dietrich. Número 4, São Paulo, 2008.

Acesso em "dia/mês/ano". 